\title{
FACTORS AFFECTING BONE TEMPERATURE INCREASE DURING IMPLANT SURGERY - REVIEW
}

\author{
Elitsa Sabeva \\ Department of Periodontology and Dental Implantology, Faculty of Dental Medicine, \\ Medical University of Varna
}

\begin{abstract}
INTRODUCTION: During implant surgery certain amount of heat is produced. It is known that temperature increase above the critical threshold of $47^{\circ} \mathrm{C}$ for a minute could lead to thermal osteonecrosis, which could be the reason for an early implant failure.

AIM: The aim of this review was to reveal the multifactorial nature of bone temperature rise during dental implant surgery.

MATERIALS AND METHODS: PubMed and Google Scholar databases were searched to select articles related to the topic. The review includes articles published from 1972 to 2019, only in English language.

RESULTS: All reviewed original articles, describing studies, whose aim was to observe the heat generation during implant surgery, are experimental. A few reviews were included. As potential risk factors for thermal damage of the bone were considered the site preparation protocol, drill wear, drill design, drilling speed and cooling effectiveness.

CONCLUSION: Heat generation during implant site preparation could be increased by performing guided implant or piezoelectric surgery. The use of combined irrigation at higher speeds, sharper drills and laser-assisted osteotomy could help avoid the risk of thermal damage to the bone. The heat production during the implant site preparation is a subject to many studies, but there is still a lack of data about the temperature rise during implant insertion.
\end{abstract}

Keywords: heat generation, implant site preparation, temperature

Address for correspondence:

Elitsa Sabeva

Faculty of Dental Medicine

Medical University of Varna

84 Tzar Osvoboditel Blvd

9000 Varna

e-mail:Elitsa.Sabeva@mu-varna.bg

\section{INTRODUCTION}

During implant surgery a certain amount of heat is produced. It is known that temperature increase above the critical threshold of $47^{\circ} \mathrm{C}$ for a minute could lead to thermal osteonecrosis, which could be the reason for an early implant failure.

Received: May 11, 2019

Accepted: June 2, 2019 


\section{AIM}

The aim of this review was to reveal the multifactorial nature of the bone temperature rise during dental implant surgery.

\section{MATERIALS AND METHODS}

PubMed and Google Scholar databases were searched to select articles related to the topic. The review includes articles published from 1972 to 2019, only in English language. The search was performed using a combination of different keywords such as: "implant", "heat generation", "temperature", "cooling", "irrigation", "drill wear", "infrared thermography", "thermocouples", "placement", "insertion", "site preparation", "osteotomy", "ultrasonic", "piezoelectric", "laser", "guided”, “drilling speed”, "load”.

The critical temperature, leading to thermal osteonecrosis is $47^{\circ} \mathrm{C}$ for one minute (1).

According to the literature review data, heat generation during the implant site preparation is mostly measured using thermocouples and infrared thermography (2-11).

Comparing both methods Harder et al. (12) considered thermography as more reliable in terms of measuring the intraosseous heat production during implant bone bed preparation. Möhlhenrich et al. (2) also recommended the use of infrared thermography for heat generation assessment.

Different biomechanical factors influence the increase in temperature during the preparation of osteotomy. Bone temperature rise is a result of multiple factors, and it should be decreased in order to achieve better tissue healing (13).

Different Site Preparation Methods and Conventional Drilling

$\diamond$ Guided Implant Surgery

Frösch et al. (14) compared the heat generation during guided osteotomy preparation with that generated during a conventional approach. For both methods they performed a single and sequential drilling protocol. The osteotomy was done in polyurethane foam blocks and the heat development was assessed using an infrared camera. Their results demonstrated that guided osteotomy preparation as well as sequential drilling leads to heat generation. Authors suggest single drilling protocol during guided implant surgery in order to decrease the temperature rise (14). Other authors also conducted similar study (15). Investigating the subsequent bone temperature increase during freehand and guided bone drilling, especially the influence of metal-on-metal contact during guided osteotomy, Barrak et al. (15) concluded that the metal sleeve contributed significantly to the temperature rise. During guided implant surgery temperature could be controlled using appropriate drilling speed and irrigation solution cooled to certain temperature $(16,17)$. Misir et al. (18) concluded that the guided implant surgery led to higher temperature increase than the conventional approach.

$\diamond$ Reduced Number of Drills

El-Kholey et al. (19) prepared 120 implant beds into bovine ribs. Half of the osteotomies in the same diameter group were done using only the pilot and the final drill and the other half were performed by the conventional drilling protocol. Heat generation was measured using thermocouple and a sensitive thermometer. The authors came to the following conclusion: both techniques lead to a development of similar temperature. Mihali et al. (20) suggested that drilling protocol including only the first and the last drill is safe for implant bed preparation. The authors also commented, that the mentioned protocol was significantly less time-consuming than the conventional approach. In an experimental study it was established that implant site preparation protocol using only one drill in type IV bone, performed under the following conditions: drilling speed of 50, 150 and $300 \mathrm{rpm}$, without cooling, led to a temperature rise that did not exceed $47^{\circ} \mathrm{C}$ (21). In another study it was concluded that the single drilling approach could lead to a higher temperature rise than the conventional drilling protocol (10).

$\diamond$ Ultrasonic Implant Site Preparation

Ultrasonic implant bone bed preparation is a highly accurate method (22), which demonstrates certain advantages, such as less pain and swelling (23).

Rashad et al. (24) observed higher heat generation with the ultrasonic implant bed preparation, whose performance requires more time. According to the authors higher temperature rise during the ultrasonic approach could be decreased with a higher level of irrigation. Other authors also established significantly higher heat production during osteotomy 
using piezosurgery unit compared to the conventional drilling (25). Stelzle et al. (26) concluded that the implant bed preparation using piezoelectric surgery should be performed with a maximum load of 400 $\mathrm{g}$ to avoid thermal tissue changes. The authors also compared the duration of the implant bed preparation using piezoelectric surgery, spiral and trephine burs and concluded that the first one required more time. The results obtained in other study were as follows: the temperature that was generated during the use of both systems - rotary burs and piezoelectric tips was safe in regard to tissue healing (27).

\section{$\diamond$ Laser-Assisted Preparation}

Although dental lasers are frequently used for the purpose of periodontal treatment (28-30), they could also be used for implant site preparation (3136). During the laser-assisted implant site preparation the bone heat generation was monitored because of the risk of thermal trauma on soft and hard tissue (31). According to Zeitouni et al. (33) the laser bone bed preparation resulted in a reduced thermal damage compared to the conventional drilling. The right selection of the wavelength and parameters of the laser plays a key role in avoiding the possibility of thermal bone trauma (34). Although osteotomy preparation using a bur is less time-consuming, the use of Er:YAG laser seems to cause less thermal damage of the bone. Comparing the three instruments for osteotomy - bur, Er:YAG laser and Er,Cr:YSGG, the latter was the only one, which caused carbonization (37).

\section{Drill Wear}

The different roughness of the drill surface could lead to different heat generation during drilling (38). Lower temperature rise was observed with sharper drills (39). Other authors also support the point that the use of worn drills leads to much higher heat generation than that of the new ones (40). Ercoli et al. (41) concluded that the bone bed could be prepared safely with drills that were used several times. Fugito Junior et. al (27) concluded that the wear of rotary burs, as well as the wear of piezoelectric tips, did not lead to a significant temperature rise after the preparation of 30 implant beds. Er et al. (42) conducted a study, whose aim was to extend the lifetime of the implant drill and its performance by using heatand wear-resistant protective coatings to decrease the alveolar bone heat generation during the osteoto- my procedure. Other authors also support the opinion that the number of uses of the drills affects the generated temperature during osteotomy $(43,44)$.

\section{Drill Design}

According to Scarano et al. (45), who used infrared thermography to detect the differences in heat production during implant site preparation with conical and with straight drills, the drill geometry is an important factor with respect to heat generation. Other authors came to the similar conclusion (44).

Other authors also did not observe a relationship between the temperature rise and drill design in the single-drilling approach using speed in the range of 50 to $300 \mathrm{rpm}(21)$.

It was established that the drill diameter affected the heat generation (10). It was observed that the twist drills even of a smaller diameter $(2 \mathrm{~mm})$ caused higher heat generation than the conical drills of a larger diameter $(3.5 \mathrm{~mm})$ (46). Comparing the temperature rise during drilling using drills made of ceramic and stainless steel, Sumer et al. (47) observed statistically significantly higher temperature increase only at the osteotomy depth of $3 \mathrm{~mm}$ using ceramic drill. Measuring the heat generation at depth of 6 and $9 \mathrm{~mm}$ they did not establish any significant difference between stainless steel and ceramic drills.

\section{Drilling Speed}

Drilling speed during osteotomy is one of the factors affecting the bone temperature increase $(16,17,39,48-50)$. Temperature rise was positively influenced by the drilling speed, when it increased from $400 \mathrm{rpm}$ to $10000 \mathrm{rpm}$ (48). Other authors also commented on the direct relationship between higher rotational speed and heat generation (39). For guided implant surgery drilling speed of $800 \mathrm{rpm}$ was proposed (16) and drilling speed of $1500 \mathrm{rpm}$ and 2000 rpm led to heat generation that exceeded the critical threshold (17).

Comparing the temperature rise during drilling with a speed of $1225 \mathrm{rpm}, 1667 \mathrm{rpm}$, and 2500 rpm Sharawy et al. (49) found the higher drilling speed used as a safest from a bone overheating standpoint. Using a speed of $2000 \mathrm{rpm}, 30000 \mathrm{rpm}$ and $400000 \mathrm{rpm}$ Iyer et al. (50) established an inverse relationship between the temperature increase and the drill speed. 
In regard to the bone temperature rise during drilling the combined effect of the drilling speed and the pressure applied was commented $(48,51)$.

\section{Applied pressure}

Commonly used pressure is about $2 \mathrm{~kg}$ $(2,18,47,52,53)$. Lajolo et al. (25) did not establish a statistically significant effect of pressure load of $1 \mathrm{~kg}$ and $1.5 \mathrm{~kg}$ on the heat production. Rashad et al. (24) did not observe a difference in the heat generation with higher loading. At speed of $400 \mathrm{rpm}$ and 800 $\mathrm{rpm}$ the increase of the drilling load from $0.8 \mathrm{~kg}$ to 2 $\mathrm{kg}$ had little influence on temperature rise (48).

There is a temperature rise at the implant surface during nonsurgical procedures $(54,55)$, as the generated heat could also be transferred to the surrounding bone $(56,57)$.

\section{Cooling}

Implant site preparation using inadequate cooling methods could lead to thermal trauma of the bone, followed by cortical bone resorption and failure of the implant treatment (58).

There is a difference between the heat produced during implant bed preparation using internal and external cooling (59).

In an ex vivo study it was established that the combination of internal and external irrigation leads to a significantly lower heat generation compared to external irrigation only (6). Another study compared the temperature rise caused by internal, double and external irrigation of conical drills and concluded that the latter led to significantly higher temperature increase than the other two mentioned (46). Trisi et al. (58) also considered internal and combination of internal and external irrigation more reliable than external irrigation only. The authors also reported extreme cortical bone resorption around implants inserted into sites prepared without irrigation. Another study also established that double irrigation and internal irrigation caused less heat generation than external cooling (52). There is an implant site preparation protocol, where only the pilot drill is with external irrigation and the following drills are with combined irrigation - internal and external (60).

Sindel et al. (61) investigated the impact of the irrigation volume on the bone temperature rise during implant surgery. The measurements were done using thermocouples inserted into a sheep mandible bone. The heat generation was assessed in three irrigation groups: without irrigation and with a physiological saline irrigation of $12 \mathrm{~mL} / \mathrm{min}$ and $30 \mathrm{~mL} /$ $\min$. While the heat generation in the no-irrigation group was significantly higher than that of the other two groups, included in the study, no statistically significant difference between both irrigation groups: $12 \mathrm{~mL} / \mathrm{min}$ and $30 \mathrm{~mL} / \mathrm{min}$, was observed. According to the authors the amount of heat produced during drilling did not correspond directly to the volume of the cooling solution. Certain irrigation solution volume is enough with regard to safe implant site preparation, while additional cooling could lead to impaired visibility in the area. Other authors used infrared thermography to assess the heat production during preparation using cooling solutions of different temperature (62). The effect of the irrigation solution volume on the heat production at the cortical bone area depends also on the implant site preparation technique. It was established that higher irrigation during the ultrasonic approach led to decreased temperature rise in the cortical bone, while the same relationship was not observed with the conventional drilling technique. This effect of the cooling during ultrasonic implant bed preparation was associated with a significant difference in the temperature between the cortical and the cancellous bone (24).

For guided implant bed preparation the use of $10{ }^{\circ} \mathrm{C}$ cooling solution was considered safe in regard to the temperature rise $(16,17)$.

Comparing the heat production during experimental preparation using drilling speed of $50 \mathrm{rpm}$ without irrigation and drilling speed of $1500 \mathrm{rpm}$ with irrigation, Oh et al. (63) did not observe any statistically significant difference between the temperature rise in both groups. Other authors also established that although the absence of irrigation at drilling speed of 50, 150 and $300 \mathrm{rpm}$ caused temperature increase, it did not rise above $47^{\circ} \mathrm{C}$ (21). Lowspeed drilling at $50 \mathrm{rpm}$ without irrigation seemed to be safe in terms of bone overheating (64). According to another study the critical threshold was exceeded with a speed of $1500 \mathrm{rpm}$ without irrigation (62).

Flanagan (65) and Marković et al. (66) investigated the heat generated during implant insertion using thermocouples. According to Summer et al. (67) 
manual placement of an implant and insertion at speeds of $30 \mathrm{rpm}$ and $50 \mathrm{rpm}$ leads to lower heat generation compared to insertion at $100 \mathrm{rpm}$. Infrared thermal camera was also used to observe the temperature increase during implant insertion (68). It was establish that the temperature rise during implant insertion could be reduced by placing tapered, shorter and smaller diameter implants (68).

\section{RESULTS}

All reviewed original articles describing studies, whose aim was to observe heat generation during implant surgery, are experimental. Among all of them only four were related to the temperature rise during implant insertion as the subject of the majority of the articles was heat generation during implant site preparation. A few reviews were included. The site preparation protocol, drill wear, drill design, drilling speed and the cooling effectiveness were considered potential risk factors for thermal damage of the bone.

\section{DISCUSSION}

Although it was established that the temperature rise during guided implant bed preparation could be controlled by the right choice of available options $(14,16,17)$, it seems that the conventional drilling is the safer approach $(14,15,18)$.

The reduced drill number protocol, including two drills, seems to be safe enough for implant site preparation $(19,20)$, leading to heat generation comparable to that caused by the use of conventional drilling (19).

The use of the piezosurgery unit leads to higher temperature rise during osteotomy $(24,25)$ and is more time-consuming than the conventional proto$\operatorname{col}(23,24,26)$. To minimize the risk of thermal trauma of the bone, the method should be performed under the following conditions: higher level (24) of irrigation and maximum load of $400 \mathrm{~g}(26)$.

With the right selection of wavelength and other parameters (34), laser-assisted osteotomy could be used as an alternative to conventional drilling from a safety standpoint, resulting in even less thermal damage $(33,37)$. However, it should be taken into account that laser osteotomy consumes more time than bone drilling (37).
Most of the authors support the opinion, that the wear of the drills affects the heat generation during implant site preparation $(38,40,43,44)$. Some authors considered the acceptable number of uses of the drills $(27,44,69)$.

In regard to the effect of the drill design on heat generation during osteotomy, the results reported by the different authors are controversial. Both theories were supported, with a little prevalence of the design significance theory $(45,44,46)$ over the opposite one (21).

Implant bone bed preparation without irrigation is acceptable during low-speed drilling at $50 \mathrm{rpm}$ $(21,63,64)$. At higher speed the use of cooling solution is required (62), as the internal and the combination of the external and internal irrigation are superior compared to external irrigation only $(6,46,52,58)$. Although according to some authors the increase of the drilling speed affects the temperature rise directly $(39,48)$, it should be taken into account that lower speed drilling consumes more time (21) and the combination of the increased temperature and its duration could lead to thermal bone trauma (70). Another parameter, which affects the drilling time is the applied load. An inverse relationship between the square of the load and the durability of the drilling was found (48). It was established that the bone temperature rise could be the result either of the higher speed or of the higher load, but the combination of both at same time did not lead to significant heat generation (51).

\section{CONCLUSION}

The heat generation during implant site preparation could be increased by performing guided implant or piezoelectric surgery. The use of combined irrigation at higher speeds, sharper drills and laserassisted osteotomy could help avoid the risk of thermal damage to the bone. The heat production during implant site preparation is a subject of many studies, but there is still a lack of data about temperature rise during implant insertion.

\section{REFERENCES}

1. Eriksson AR, Albrektsson T. Temperature threshold levels for heat-induced bone tissue injury: a vital-microscopic study in the rabbit. J Prosthet Dent. 1983;50(1):101-7. doi: 10.1016/0022-3913(83)90174-9. 
2. Möhlhenrich SC, Modabber A, Steiner T, Mitchell DA, Hölzle F. Heat generation and drill wear during dental implant site preparation: systematic review. Br J Oral Maxillofac Surg. 2015;53(8):679-89. doi: 10.1016/j.bjoms.2015.05.004.

3. Bulloch SE, Olsen RG, Bulloch B. Comparison of heat generation between internally guided (cannulated) single drill and traditional sequential drilling with and without a drill guide for dental implants. Int J Oral Maxillofac Implants. 2012;27(6):1456-60.

4. Liu YF, Wu JL, Zhang JX, Peng W, Liao WQ. Numerical and experimental analyses on the temperature distribution in the dental implant preparation area when using a surgical guide. J Prosthodont. 2018;27(1):42-51. doi: 10.1111/jopr.12488.

5. Boa K, Barrak I, Varga E Jr, Joob-Fancsaly A, Varga E, Piffko J. Intraosseous generation of heat during guided surgical drilling: an ex vivo study of the effect of the temperature of the irrigating fluid. Br J Oral Maxillofac Surg. 2016; 54(8):904-8. doi:10.1016/j.bjoms.2016.06.004.

6. Gehrke SA, Aramburú Júnior JS, Pérez-Albacete Martínez C, Ramirez Fernandez MP, Maté Sánchez de Val JE, Calvo-Guirado JL. The influence of drill length and irrigation system on heat production during osteotomy preparation for dental implants: an ex vivo study. Clin Oral Implants Res. 2018;29(7):772-8. doi: 10.1111/clr.12827.

7. Oh HJ, Wikesjö UM, Kang HS, Ku Y, Eom TG, Koo KT. Effect of implant drill characteristics on heat generation in osteotomy sites: a pilot study. Clin Oral Implants Res. 2011;22(7):722-6. doi: 10.1111/j.1600-0501.2010.02051.x.

8. Oh JH, Fang Y, Jeong SM, Choi BH. The effect of low-speed drilling without irrigation on heat generation: an experimental study. J Korean Assoc Oral Maxillofac Surg. 2016;42(1):9-12. doi: 10.5125/ jkaoms.2016.42.1.9.

9. Mishra SK, Chowdhary R. Heat generated by dental implant drills during osteotomy-a review: heat generated by dental implant drills. J Indian Prosthodont Soc. 2014;14(2):131-43. doi: 10.1007/ s13191-014-0350-6.

10. Möhlhenrich SC, Abouridouane M, Heussen N, Hölzle F, Klocke F, Modabber A. Thermal evaluation by infrared measurement of implant site preparation between single and gradual drilling in artificial bone blocks of different densities. Int J Oral Maxillofac Surg. 2016; 45(11):1478-84. doi: 10.1016/j.ijom.2016.05.020.
11. Möhlhenrich SC, Abouridouane M, Heussen N, Modabber A, Klocke F, Hölzle F. Influence of bone density and implant drill diameter on the resulting axial force and temperature development in implant burs and artificial bone: an in vitro study. Oral Maxillofac Surg. 2016;20(2):135-42. doi: 10.1007/s10006-015-0536-Z.

12. Harder S, Egert C, Freitag-Wolf S, Mehl C, Kern $\mathrm{M}$. Intraosseous temperature changes during implant site preparation: in vitro comparison of thermocouples and infrared thermography. Int J Oral Maxillofac Implants. 2018;33(1):72-8. doi: 10.11607/ jomi.6222.

13. Chauhan CJ, Shah DN, Sutaria FB. Various biomechanical factors affecting heat generation during osteotomy preparation: A systematic review. Indian J Dent Res. 2018;29(1):81-92. doi: 10.4103/ijdr. IJDR_729_16.

14. Frösch L, Mukaddam K, Filippi A, Zitzmann NU, Kühl S. Comparison of heat generation between guided and conventional implant surgery for single and sequential drilling protocols - an in vitro study. Clin Oral Implants Res. 2019;30(2):121-130. doi: 10.1111/clr.13398.

15. Barrak I, Joób-Fancsaly Á, Braunitzer G, Varga E Jr, Boa K, Piffkó J. Intraosseous heat generation during osteotomy performed freehand and through template with an integrated metal guide sleeve: an in vitro study. Implant Dent. 2018;27(3):342-50. doi: 10.1097/ID.0000000000000763.

16. Barrak I, Joób-Fancsaly A, Varga E, Boa K, Piffko J. Effect of the combination of low-speed drilling and cooled irrigation fluid on intraosseous heat generation during guided surgical implant site preparation: an in vitro study. Implant Dent. 2017

17. Barrak I, Boa K, Joób-Fancsaly Á, Varga E, Sculean A, Piffkó J. Heat Generation During Guided and Freehand Implant Site Preparation at Drilling Speeds of 1500 and 2000 RPM at Different Irrigation Temperatures: An In Vitro Study. Oral Health Prev Dent. 2019;1-8. doi: 10.3290/j.ohpd.a42507.

18. Misir AF, Sumer M, Yenisey M, Ergioglu E. Effect of surgical drill guide on heat generated from implant drilling. J Oral Maxillofac Surg. 2009;67(12):2663-8. doi: 10.1016/j.joms.2009.07.056.

19. El-Kholey KE, Ramasamy S, Kumar RS, Elkomy A. Effect of simplifying drilling technique on heat generation during osteotomy preparation for dental implant. Implant Dent. 2017;26(6):888-91. doi: 10.1097/ID.0000000000000692. 
20. Mihali SG, Canjau S, Cernescu A, Bortun CM, Wang HL, Bratu E. Effects of a short drilling implant protocol on osteotomy site temperature and drill torque. Implant Dent. 2018;27(1):63-8. doi: 10.1097/ID.0000000000000707.

21. Delgado-Ruiz RA, Velasco Ortega E, Romanos GE, Gerhke S, Newen I, Calvo-Guirado JL. Slow drilling speeds for single-drill implant bed preparation. Experimental in vitro study. Clin Oral Investig. 2018;22(1):349-359. doi: 10.1007/s00784-017-2119-x.

22. Scarano A, Iezzi G, Perrotti V, Tetè S, Staiti G, Mortellaro C, et al. Ultrasonic versus drills implant site preparation: a histologic analysis in bovine ribs. J Craniofac Surg. 2014;25(3):814-7. doi: 10.1097/ SCS.0000000000000713.

23. 23 Scarano A, Carinci F, Lorusso F, Festa F, Bevilacqua L, Santos de oliveira p, et al. Ultrasonic vs drill implant site preparation: post-operative pain measurement through VAS, swelling and crestal bone remodeling: a randomized clinical study. Materials (Basel). 2018;11(12). pii: E2516. doi: 10.3390/ ma11122516.

24. Rashad A, Kaiser A, Prochnow N, Schmitz I, Hoffmann E, Maurer P. Heat production during different ultrasonic and conventional osteotomy preparations for dental implants. Clin Oral Implants Res. 2011;22(12):1361-5. doi:10.1111/j.1600-0501.2010.02126.x.

25. Lajolo C, Valente NA, Romandini WG, Petruzzi M, Verdugo F, D’Addona A. Bone heat generated using conventional implant drills versus piezosurgery unit during apical cortical plate perforation. J Periodontol. 2018;89(6):661-8. doi:10.1002/ JPER.17-0502.

26. Stelzle F, Frenkel C, Riemann M, Knipfer C, Stockmann P, Nkenke E. The effect of load on heat production, thermal effects and expenditure of time during implant site preparation - an experimental ex vivo comparison between piezosurgery and conventional drilling. Clin Oral Implants Res. 2014;25(2):e140-8. doi: 10.1111/clr.12077.

27. Fugito Junior K, Cortes AR, de Carvalho Destro R, Yoshimoto M. Comparative study on the cutting effectiveness and heat generation of rotary instruments versus piezoelectric surgery tips using scanning electron microscopy and thermal analysis. Int J Oral Maxillofac Implants. 2018;33(2):345-50. doi: 10.11607/jomi.5806.
28. Miteva M, Peev S, Hristov I. The adjunctive use of the Er,Cr:YSGG laser in nonsurgical periodontal treatment. Int J Sci Res (IJSR). 2017;6(4):61-4.

29. Miteva M, Peev S, Hristov I. Management of chronic generalized periodontitis by adjunctive use of diode laser. Int J Sci Res (IJSR). 2017;6(4):65-7.

30. Zhou X, Lin M, Zhang D, Song Y, Wang Z. Efficacy of Er:YAG laser on periodontitis as an adjunctive non-surgical treatment: A split-mouth randomized controlled study. J Clin Periodontol. 2019;46(5):53947. doi: 10.1111/jcpe.13107.

31. Semez G, Luca RE, Cescato A, Faoro V, Mocuţa DE, Todea DCM. Effect of the laser beam on implant site preparation: a preliminary pilot study. Rom J Morphol Embryol. 2018;59(3):861-7.

32. Tretto PHW, Fabris V, Cericato GO, Sarkis-Onofre R, Bacchi A. Does the instrument used for the implant site preparation influence the boneimplant interface? A systematic review of clinical and animal studies. Int J Oral Maxillofac Surg. 2019;48(1):97-107. doi: 10.1016/j.ijom.2018.04.005.

33. Zeitouni J, Clough B, Zeitouni S, Saleem M, Al Aisami K, Gregory C. The effects of the Er:YAG laser on trabecular bone micro-architecture: Comparison with conventional dental drilling by micro-computed tomographic and histological techniques. F1000Res. 2017;6:1133. doi: 10.12688/ f1000research.12018.1.

34. Moslemi N, Shahnaz A, Masoumi S, Torabi S, Akbari S. Laser-assisted osteotomy for implant site preparation: a literature review. Implant Dent. 2017

35. Stübinger S, Biermeier K, Bächi B, Ferguson SJ, Sader R, von Rechenberg B. Comparison of Er:YAG laser, piezoelectric, and drill osteotomy for dental implant site preparation: a biomechanical and histological analysis in sheep. Lasers Surg Med. 2010;42(7):652-61. doi: 10.1002/lsm.20944.

36. Kesler G, Romanos G, Koren R. Use of Er:YAG laser to improve osseointegration of titanium alloy implants--a comparison of bone healing. Int J Oral Maxillofac Implants. 2006;21(3):375-9.

37. de Oliveira GJ, Rodrigues CN, Perussi LR, de Souza Rastelli AN, Marcantonio RA, Berbert FL. Effects on bone tissue after osteotomy with different highenergy lasers: an ex vivo study. Photomed Laser Surg. 2016;34(7):291-6. doi: 10.1089/pho.2015.3917.

38. Marenzi G, Sammartino JC, Quaremba G, Graziano V, El Hassanin A, Qorri ME, et al. Clinical influence of micromorphological structure 
of dental implant bone drills. Biomed Res Int. 2018;2018:8143962. doi: 10.1155/2018/8143962.

39. Pirjamalineisiani A, Jamshidi N, Sarafbidabad M, Soltani N. Assessment of experimental thermal, numerical, and mandibular drilling factors in implantology. Br J Oral Maxillofac Surg. 2016;54(4):400-4. doi: 10.1016/j.bjoms.2015.09.017.

40. Matthews LS, Hirsch C. Temperature measured in human cortical bone when drilling. J Bone Joint Surg Am. 1972;54:297-308.

41. Ercoli C, Funkenbusch PD, Lee HJ, Moss ME, Graser GN. The influence of drill wear on cutting efficiency and heat production during osteotomy preparation for dental implants: a study of drill durability. Int J Oral Maxillofac Implants. 2004;19(3):335-49.

42. Er N, Alkan A, Ilday S, Bengu E. Improved dental implant drill durability and performance using heat and wear resistant protective coatings. J Oral Implantol. 2018

43. Hochscheidt CJ, Shimizu RH, Andrighetto AR, Moura LM, Golin AL, Hochscheidt RC. Thermal variation during osteotomy with different dental implant drills: a standardized study in bovine ribs. Implant Dent. 2017;26(1):73-9. doi: 10.1097/ ID.0000000000000535.

44. Chacon GE, Bower DL, Larsen PE, McGlumphy EA, Beck FM. Heat production by 3 implant drill systems after repeated drilling and sterilization. J Oral Maxillofac Surg. 2006

45. Scarano A, Piattelli A, Assenza B, Carinci F, Di Donato L, Romani GL, et al. Infrared thermographic evaluation of temperature modifications induced during implant site preparation with cylindrical versus conical drills. Clin Implant Dent Relat Res. 2011;13(4):319-23. doi: 10.1111/j.1708-8208.2009.00209.x.

46. Strbac GD, Giannis K, Unger E, Mittlböck M, Vasak C, Watzek G, Zechner W. Drilling- and withdrawing-related thermal changes during implant site osteotomies. Clin Implant Dent Relat Res. 2015;17(1):32-43. doi: 10.1111/cid.12091.

47. Sumer M, Misir AF, Telcioglu NT, Guler AU, Yenisey M. Comparison of heat generation during implant drilling using stainless steel and ceramic drills. J Oral Maxillofac Surg. 2011

48. Reingewirtz Y, Szmukler-Moncler S, Senger B. Influence of different parameters on bone heating and drilling time in implantology. Clin Oral Implants Res. 1997;8(3):189-97.

49. Sharawy M, Misch CE, Weller N, Tehemar S. Heat generation during implant drilling: the significance of motor speed. J Oral Maxillofac Surg. 2002;60(10):1160-9.

50. Iyer S, Weiss C, Mehta A. Effects of drill speed on heat production and the rate and quality of bone formation in dental implant osteotomies. Part I: Relationship between drill speed and heat production. Int J Prosthodont. 1997;10(5):411-4.

51. Brisman D. The effect of speed, pressure, and time on bone temperature during the drilling of implant sites. Int J Oral Maxillofac Implants. 1996;11(1):35-7.

52. Bulloch SE, Olsen RG, Bulloch B. Comparison of heat generation between internally guided (cannulated) single drill and traditional sequential drilling with and without a drill guide for dental implants. Int J Oral Maxillofac Implants. 2012;27(6):1456-60.

53. Cordioli G, Majzoub Z. Heat generation during implant site preparation: an in vitro study. Int J Oral Maxillofac Implants. 1997

54. 54. Aleisa K, Alkeraidis A, Al-Dwairi ZN, Altahawi H, Lynch E. Implant fixture heat transfer during abutment preparation. J Oral Implantol. 2015;41(3):264-7. doi: 10.1563/ AAID-JOI-D-13-00056.

55. Al-Keraidis A, Aleisa K, Al-Dwairi ZN, AlTahawi H, Hsu ML, Lynch E, et al. Heat generation on implant surface during abutment preparation at different elapsed time intervals. Implant Dent. 2017;26(5):700-5. doi: 10.1097/ ID.0000000000000600.

56. Arias SR, Rueggeberg FA, Mettenburg D, Sharawy M, Looney S, Elsayed R, et al. Heat generation during removal of an abutment screw fragment from dental implants. J Prosthet Dent. 2018;119(4):620-5. doi: 10.1016/j.prosdent.2017.06.011.

57. Huh JB, Eckert SE, Ko SM, Choi YG. Heat transfer to the implant-bone interface during preparation of a zirconia/alumina abutment. Int J Oral Maxillofac Implants. 2009;24(4):679-83.

58. Trisi P, Berardini M, Falco A, Podaliri Vulpiani M, Perfetti G. Insufficient irrigation induces peri-implant bone resorption: an in vivo histologic analysis in sheep. Clin Oral Implants Res. 2014;25(6):696701. doi: $10.1111 /$ clr.12127. 
59. Harder S, Egert C, Wenz HJ, Jochens A, Kern M. Influence of the drill material and method of cooling on the development of intrabony temperature during preparation of the site of an implant. $\mathrm{Br} \mathrm{J}$ Oral Maxillofac Surg. 2013;51(1):74-8. doi: 10.1016/j. bjoms.2012.02.003.

60. Peev S, Atanasov D. Platelet-rich plasma - an accelerator of the secondary stability of immediate loaded implants. J IMAB - Annual Proceeding (Scientific Papers). 2007;2:38-40.

61. Sindel A, Dereci Ö, Hatipoğlu M, Altay MA, Özalp Ö, Öztürk A. The effects of irrigation volume to the heat generation during implant surgery. Med Oral Patol Oral Cir Bucal. 2017;22(4):e506-e511. doi: 10.4317/medoral.21880.

62. Kirstein K, Dobrzyński M, Kosior P, Chrószcz A, Dudek K, Fita K, et al. Infrared Thermographic Assessment of Cooling Effectiveness in Selected Dental Implant Systems. Biomed Res Int. 2016;2016:1879468. doi: 10.1155/2016/1879468.

63. Oh JH, Fang Y, Jeong SM, Choi BH. The effect of low-speed drilling without irrigation on heat generation: an experimental study. J Korean Assoc Oral Maxillofac Surg. 2016 Feb;42(1):9-12. doi: 10.5125/ jkaoms.2016.42.1.9.

64. Kim SJ, Yoo J, Kim YS, Shin SW. Temperature change in pig rib bone during implant site preparation by low-speed drilling. J Appl Oral Sci. 2010;18(5):522-7. doi: 10.1590/ s1678-77572010000500016.
65. Flanagan D. Heat generated during seating of dental implant fixtures. J Oral Implantol. 2014;40(2):174-81. doi: 10.1563/ AAID-JOI-D-13-00261.

66. Marković A, Mišić T, Miličić B, Calvo-Guirado JL, Aleksić Z, Đinić A. Heat generation during implant placement in low-density bone: effect of surgical technique, insertion torque and implant macro design. Clin Oral Implants Res. 2013;24(7):798-805. doi: 10.1111/j.1600-0501.2012.02460.x.

67. Sumer M, Keskiner I, Mercan U, Misir F, Cankaya $S$. Assessment of heat generation during implant insertion. J Prosthet Dent. 2014;112(3):522-5. doi: 10.1016/j.prosdent.2013.12.011.

68. Peev S, Sabeva E. Assessment of the heat generation at the marginal bone area during the implant insertion using infrared thermography (experimental study). Int J Sci Res (IJSR). 2016;5(9):822-5.

69. Koo KT, Kim MH, Kim HY, Wikesjö UM, Yang $\mathrm{JH}$, Yeo IS. Effects of implant drill wear, irrigation, and drill materials on heat generation in osteotomy sites. J Oral Implantol. 2015;41(2):e19-23. doi: 10.1563/AAID-JOI-D-13-00151.

70. Augustin G, Davila S, Udilljak T, Staroveski T, Brezak D, Babic S. Temperature changes during cortical bone drilling with a newly designed step drill and an internally cooled drill. Int Orthop. 2012;36(7):1449-56. doi:10.1007/s00264-012-1491-z. 